\title{
AN ANALYSIS OF URBAN REGENERATION AND ARCHITECTURAL HERITAGE SAVING IN KABUL SINCE 2001
}

\author{
BASHIR A. KAZIMEE ${ }^{1} \&$ ABDUL WASSAY NAJIMI ${ }^{2}$ \\ ${ }^{1}$ School of Design, Washington State University, USA. \\ ${ }^{2}$ The Aga Khan Trust for Culture, Kabul, Afghanistan.
}

\begin{abstract}
The tragic civil war in Afghanistan, since April 1978, has dealt a severe and destructive blow to the physical and social fabric of cities of the country. The regrettable victims in this conflict, however, which were entrapped, are the historic neighbourhoods in the cities, where fierce street-to-street fighting and use of heavy weaponry resulted in the utter destruction of their fine residential fabric and left some of the valuable historic buildings in ruin.

Like many important urban and architectural heritage in Islamic cities, Kabul evolved through the agent of continued cultural participation, which entrusted deeper meanings to its architecture and urban form. Historically, Kabul, with its wonderful traditional architecture of courtyards, lavish Timurid (later Mughal) gardens, decorated worship centres and its glowing historic bazaars that enticed trade enterprises and merchants around the region, sustained a vibrant city life for its citizens.

With an analysis of historical development and discussion of the importance of architectural and urban heritage of the historic city, this article will illustrate the post-war efforts of local and international aid organizations and their undertaking in the historical conservation process.

The article will represent a case study of Murad-Khani, a historical conservation project in the Old City of Kabul, and deliberate its impact on the neighbourhood regeneration process. It will further examine the process of revitalization of architectural and urban heritage in the Old City in light of social and economic regeneration and cultural awareness.
\end{abstract}

Keywords: architecture, conservation, social-economic regeneration, urban heritage.

\section{INTRODUCTION: HISTORICAL ANALYSIS}

The historic city of Kabul enlightens us with a wealth of cultural repositories through its architecture and urban form, which are the result of an evolving process of development through many generations. Being located on the major network of ancient trade routes, connecting India and China to the Persian trade routes and beyond to the west, the city represents many eventful layers of historical accounts that are inherently important to its development.

From archaeological excavations, Kabul's original site can be traced to the slopes of the Chakari Mountain (also known as Shewaki Mountain), which is located to the southeast of the present city, where Buddhist temples, monasteries and irrigation canals are found with intakes from the Logar River [1].

It is believed that the growth of the city continued to the northwest for defence purposes. In the holy book of Rig-Veda, dated 1200 BC, there is mention of Kubha, which refers to Kabul River. Ancient explorers observed Kabul, in 675 AD, to be an important strategic commercial and pilgrimage centre [2]. The site of Kabul at this time was protected by a defensive wall built by Kabul Shahan, on Sher-Darwaza Mountain noticeable from south east of the citadel (Bala-Hisar) and extending to the west and the Asamaee Mountain to the present DehAfghanan slopes. During this period Kabul was an agricultural community and the religion of its inhabitants was Buddhism.

In $698 \mathrm{AD}$, the Arabs invaded Kabul and took several decades to capture Kabul; as a result, Kabul suffered from the devastation of war significantly. Years later, the inhabitants of Kabul 
accepted Islam as their new religion. Islamic faith introduced with it new socio-cultural values and administration techniques [3].

In 1502 AD Zahiruddin Mohammad, later known as Babur Shah, the Mughal emperor, established Kabul as his capital. Babur Shah was very fond of Kabul and he commissioned several public construction projects including several buildings and beautiful gardens [4]. Other Mughal princes like Shahjahan and Aurangzeb built structures and mosques. In 1739 AD Kabul suffered from the invasion of the Iranian king Nader Shah Afshar and some of the city's buildings and gardens were destroyed. Nader Shah facilitated the settlement of his ethnic Qizilbash group in the Chendawol walled district that later became part of the Old City. The Afghan king Ahmad-Shah, and the founder of modern Afghanistan in 1747, ruled Kabul as a major city while his capital was established in Kandahar to easily administer Khurasan. After his death in 1773 his son Timur-Shah transferred the capital from Kandahar to Kabul in 1775-1776, primarily because of its central location, accessed by major regional trade routes and having lesser number of tribal conflicts [5, p. 340; 6]. During Timur-Shah's rule Kabul grew in prosperity and in population as the capital of the kingdom. The city maintained its social and cultural cohesiveness even though the new residential quarters were known by names of tribes and clans moving into the city. The livelihood of the inhabitants depended on nearby agricultural land and trade activities within the city.

Later, in the years 1839-1842 AD due to the conflict with a belligerent British Army, Kabul suffered a great deal of devastation. Much of its fine architecture and urban fabric was destroyed, including the great Char-Chatta Bazaar, which was one of the fine commercial establishments in the region. The bazaar was burned by the British Army in retaliation to their defeat. The Char-Chatta Bazaar was a famous commercial centre; its merchandise has been mentioned by early travellers, thus reflecting the important strategic location of Kabul between the East and West [7]. The population of Kabul at this time is estimated to be around 50,000 inhabitants.

The size of the city in the 19th century remained very much the same and the physical structure of the city possessed most elements of a traditional Islamic city. Fortification walls still enclosed the city; and the entrance to the city was controlled by several gates. Many commercial bazaars and series were the hub of the city life. Access to the city from across the Kabul River, which was located to the north of the Old City, was provided by various bridges, many of which are still in use.

It was during the later part of the 19th century that the sheer richness of the urban dynamics of the Old City was eclipsed by the implementation of modern city planning schemes, sanctioned by the rulers outside the Old City boundaries. During the rule of Amir Abdur Rahman, the new city expanded north-west and underwent great physical transformation. The amir built opulent palaces for himself outside the city, such as Arg (the citadel), Baghi-Bala and Chilsotoon palaces, as well as the Arg Bazaar, and several other lavish buildings. The amir was enchanted with the Central Asian tradition of palaces and their visual and sensual beauty, where he spent his exile before claiming the throne in Kabul. He has built ornate mansions inside spacious gardens, with elaborate architectural and landscape schemes to proclaim his royal position. It was also at this time that the amir authorized the building of a public water system for the city. The water was diverted from an upstream Kabul River and was channelled by an underground tunnel system throughout the city. At every major lane, an iron gate was provided that led through a stairway to the supply channel where the inhabitants retained their water needs. It was during the reign of his son Habibullah (1901-1919) that the piped water supply system was introduced to the city of Kabul, where the system was still in use before the recent war in the 1970s. The water was channelled to the city from a reservoir 
located in Paghman, about 17 miles to the west of the city at the southern slopes of Hindu Kush Mountain. The population of Kabul at this time was estimated to be around 160,000. Like his father, King Habibullah commissioned several additional lavish palaces and public buildings and introduced electricity and piped water supply to the city. He built the Dilkusha palace, the Eidgah mosque and the Habibia College and expanded the Arg [7, pp. 303-306].

The modernization of Kabul further intensified during the reign of his son King Amanullah (1919-1929), when he was determined to modernize and bring rigorous reforms to the country's socio-economic structure. He established his new power seat at Darul-Aman, located six miles southwest of the Old City, where a grandiose parliament building was built in elegant 18th-century-European-style architecture designed by a French architect [8]. Insistent with his modern project, a comprehensive plan was developed by French architects and German engineers for the new city. The plan called for a modern city which included provision for necessary public buildings, educational facilities, health centres, commercial and sumptuous Western style residential subdivisions, with many elegant gardens and open spaces for the leisure of citizens. A railway was established to connect the Old City to the new capital for the transfer of materials and people. Telephone services were introduced in Kabul for the first time and the capital was connected to the outside world via air traffic [9]. Amanullah, through his modernization scheme laid the foundation of modern planned urbanization. Many of his plans were followed by King Nader Shah and his successor King Zahir Shah. Kabul University was established in the early 1930s, and in the 1940s, the city began to grow as an industrial centre. In the 1960s, the city developed as a big cosmopolitan centre [9].

The antecedent planning philosophies promulgated fragmented and heterogeneous patterns of development in newer areas of the city. The modernization project of the late 19th century and the desire for Western-style modern subdivisions resulted in further marginalization of the historic city. The authorities of the time literally turned their backs on it and the city's population was left deprived of social and economic supports of the governments. The consequential gentrification of the historic fabric not only inflected damaging effect to the diversity and heritage of the historic areas, but also created a rift between rich and poor, upper elite and lower class stratum with much negative consequences (Figs. 1 and 2).

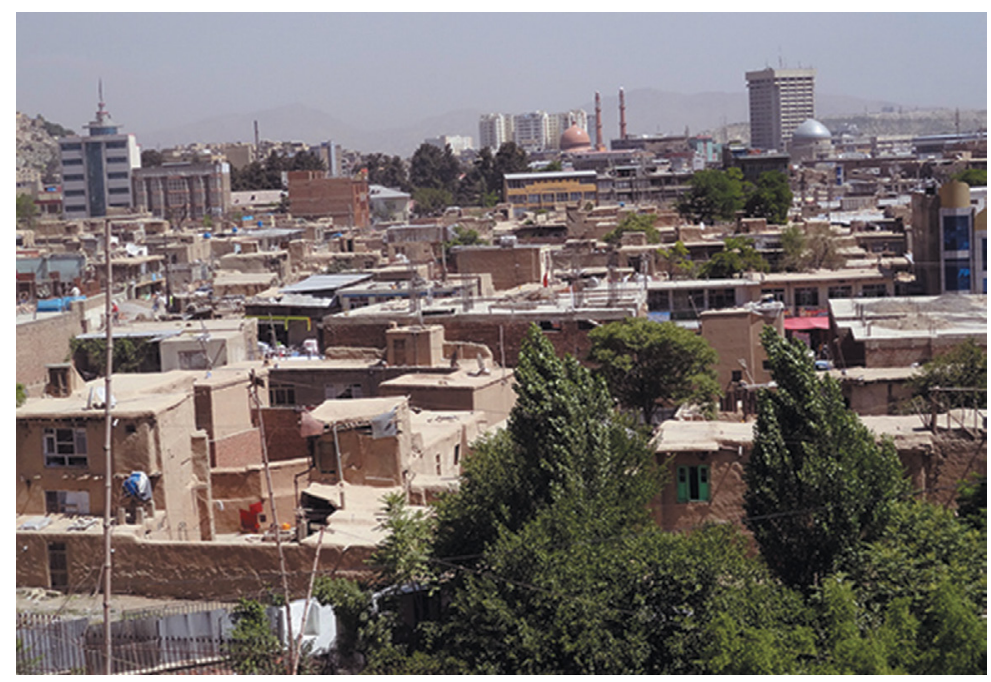

Figure 1: A panoramic view of Kabul with Old City in the foreground. 


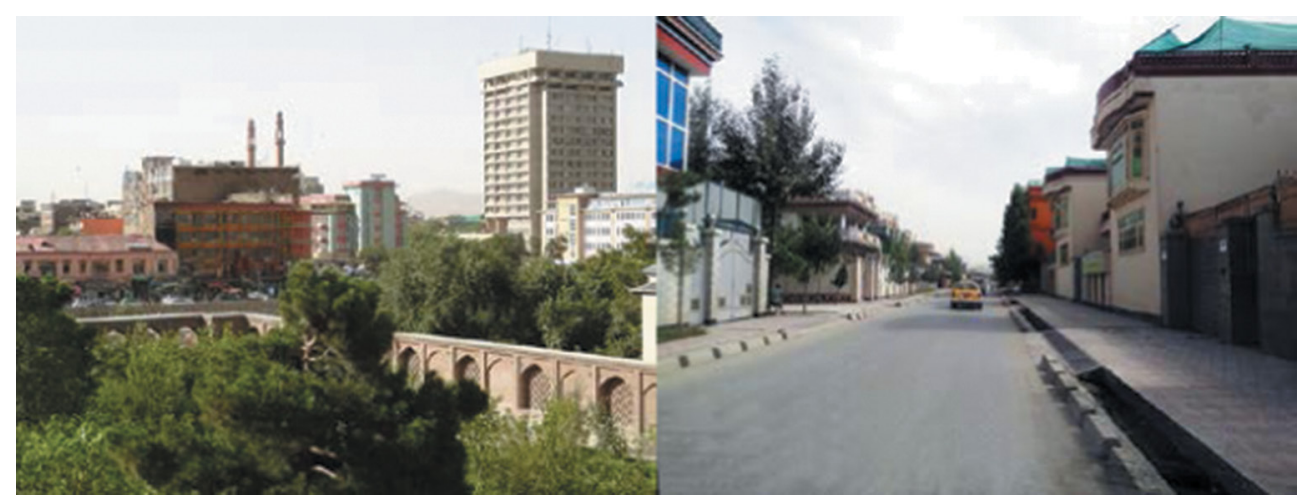

Figure 2: (a) A modern city centre. (b) A modern housing subdivision in Kabul.

In 1962 under a national economic development plan, a team of planners was invited from the Central Scientific and Research Design Institute for Town Construction of the erstwhile Soviet Union to prepare a new 25-year master plan for the city of Kabul [10]. The plan called for a total population of 1.5 million and took into account population growth and migration from rural areas. Ironically, the plan had earmarked the entire site of the Old City as a slum area that was to be replaced by new multi-storeyed apartment blocks similar to those constructed by Soviet-style four-storey housing blocks, referred to as the 'Micro-Ryan' prefabricated housing prototype familiar all across the Soviet Union.

The 25 years of war that was imposed first by the hegemonies of Soviet Union in 1978 and then by the US-led coalition forces in 2001 resulted in utter destabilization of the country, which triggered a civil war on an unimaginable scale. The most distressing effect of the civil war, however, that inflicted a blow on the properties and infrastructure of the historic city was the inter-factional street-to-street fighting of 1993-1994, which reduced much of the traditional physical fabric to rubbles. The Old City became a dire locality not to be inhabited. However, it was in 2002 that an appropriate rehabilitation and conservation programme was formulated, which encouraged the resettlement process of residents and allowed for reconstruction and repair of war-damaged properties. Between 2003 and 2005 the population of the city showed a $15 \%$ increase mainly due to the resettlement of displaced families whose homes had been damaged by war [11]. With the availability of marginal public services and very basic infrastructure, the area attracted many more migrant populations from the rural areas and elsewhere who found affordable living and access to casual employment in the area. Recent statistics on historical quarters report significant population increase and the highest residential densities in the Old City reported an average of 250 people per hectare, with most traditional homes subdivided and sublet over time [11, pp. 23-37].

\section{POST-WAR CONSERVATION AND REHABILITATION PROCESS}

With the aftermath of the 2001 military campaign in Afghanistan, an ambitious reconstruction programme was formulated for the country by both national and international organizations. Recognizing the need for the protection of historical urban heritage and cultural sites, though not a priority, meagre funding for architectural conservation work was conceived in the early stages of the reconstruction process. Initially the funds were allocated by the Greek, 


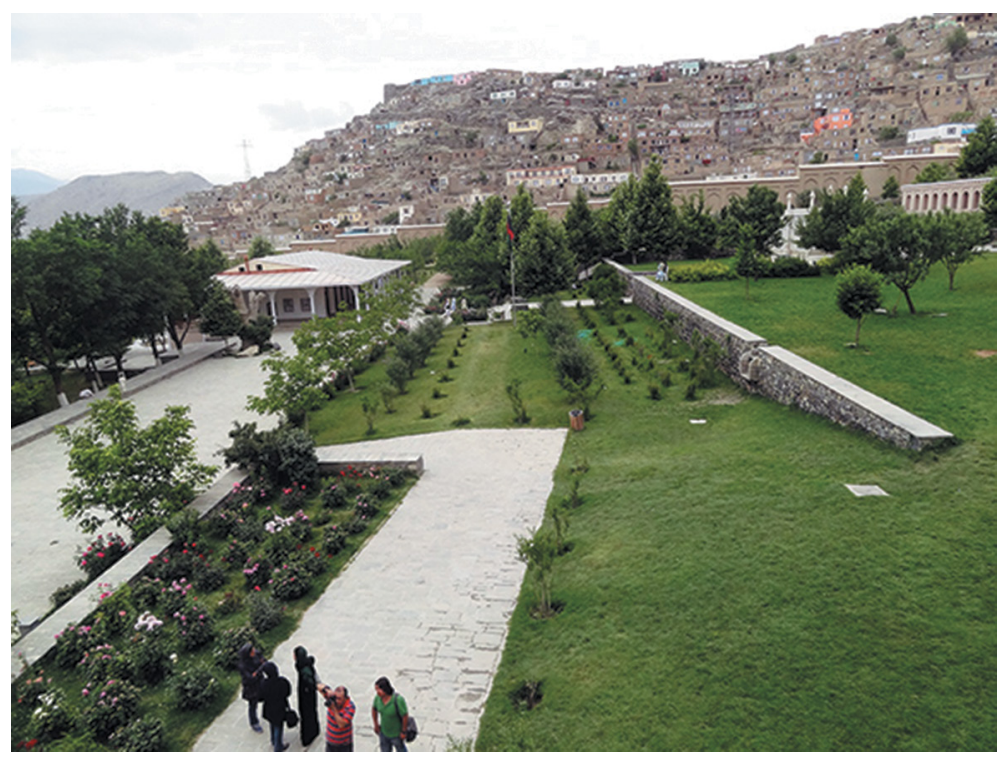

Figure 3: The Baghe-Babur (garden) was completed in 2007 by the AKTC conservation program, which provides for much of the city's recreation and cultural events.

US, Canadian and UK governments and the World Bank, channelled through the Aga Khan Trust for Culture (AKTC) foundation and its Historic Cities Programme (HCP). Since 2002 the activities of the HCP in close collaboration with community leaders, municipal representatives and the Ministry of Urban Development played an important role in the urban recovery of the Old City of Kabul as well as providing support for the conservation and reuse of historic properties across the country (Fig. 3).

Under the initiative of urban conservation and in an effort to stabilize the fragile urban fabric of the Old City, the AKTC, focused on upgrading the surrounding infrastructure in the poorer neighbourhoods and on repairing the war-damaged homes, to allow for the resettling of its displaced population. In the spirit of capacity building and institutional reform, in 2006, the Turquoise Mountain Foundation initiated conservation work in the district of Murad Khani, located north of the Kabul River, where a craft training centre is established, as part of the efforts to promote employment of Afghans [12]. Under these programmes many craftsmen and artisans were trained in the traditional techniques of building construction, carpentry and other artisan trades to help and be employed in their communities. Support for home-based activities that will help develop skills of female households such as tailoring, embroidery and gelim-weaving - all of which have potential to contribute to household livelihoods. The scope of these programmes is widely acknowledged now and the HCP programme benefited more than 50,000 people across the country and provides sustained employment opportunity for many Afghans [13].

The conservation work in the Old City has helped the residents to raise awareness as to the need of safeguarding the historic urban heritage. Meagre investment seems to effectively have heightened awareness of citizens in heritage value and the historic pride invested in their neighbourhoods [14]. 


\section{THE NEED FOR CONSERVATION OF HISTORIC QUARTERS}

\subsection{Cultural expression and the value of heritage}

Historic Afghan cities throughout centuries of their existence supported a way of life and a very splendid urban expression that came from a profound philosophical and religious backgrounds. Like many Islamic cities the new architectural style and urban development in Kabul is pursuing the modernist style of architecture that does not provide the charm of traditional Afghan places and lacks much regional fit. Afghan traditional cities and architecture are the product of centuries of development, which have direct bearing on its regional identity and sense of place. People adapted to the forces of climate and geography that resonated values beyond pragmatic comfort, but a real life impact on the shape and makeup of their built places. Traditional urban districts were identified by placid dense urban fabric endowed with much aesthetic appeal and distinguished cultural history. The role of historic Kabul is critical for benefiting from the value of heritage. Urban designers and architects need to make careful analysis of the Old City's urban attributes and carefully formulate them into coherent strategies for newer developments. By working with stakeholders, embarking on educational programmes and implementing sound design and planning policies, designers can establish their desired vision for future developments.

\subsection{Housing needs and heritage areas}

The task of providing adequate housing for the growing population in the city is extremely challenging, especially when the rate of rapid urbanization due to migration and population growth, which has a direct impact on the provision of shelter and security, is reaching its critical point. Kabul is facing acute housing problems and is not able to cope with the impact of this significant population growth. There is no evidence that the problem of shelter will subside any time soon. Historic Kabul will continue to provide viable and affordable shelter for the majority of people in this area, especially the poorer segment of the population. Upgrading the infrastructure and providing minimum of services is easy for the authorities to provide with much lower costs for the whole development compared to pricey investing options in newer subdivisions. The housing prototype that characterizes the historic city is the introverted courtyard houses which closely fit the cultural aspiration of the population and is easily adaptive to changing needs and desires of the families. With many variations the courtyard houses are instrumental to accommodating affordably with much higher densities the growing housing needs of the population.

\subsection{The economic role of heritage}

The Old City not only played an attentive role in catering to the needs of commerce and cultural activities of its own population but also contributed to the lifeline of the merchants and trade throughout the region. Their ancient importance has been prominent and described by intensity of commerce, cultural and administrative vitality. The city has had some of the richest economic and cultural resources that influenced its underlying urban fabric. The urban structure was intertwined with many ancient bazaars, commercial series and religious establishments. These important economic and cultural establishments are necessary to be revitalized in order to rejuvenate and restore the status and prestige of the Old City. Present 
observation already shows an immense concentration of commerce and merchant activities following its ancient and prewar entrepreneurial spirit.

\subsection{Tourism industry and heritage}

In recognizing the growing interest of global population in the field of tourism, the conservation of Old City will add essentially important economic, social and cultural dynamic to the city and will bring stimulus to the marketing of heritage products, for the heritage seeking tourist population. Traditional architecture, combined with the rich production of arts and crafts of Afghanistan, has been an important source of pride and devotion for its people and the demand for its articles has been an important spur behind the local industry and its market in the region. Creating and reviving the craft techniques and designs in the Old City will support the production and distribution of handmade Afghan crafts worldwide, including traditional Afghan woodwork, jewellery, ceramics, textile, jewellery and calligraphy, which will be a source of pride and vocation for families.

\subsection{Educational and research opportunities}

Preserving the architecture and urban structure of historic cities represents more than a nostalgic longing for the past and ways that have essentially became obsolete; it is rather a learning experience by which larger challenges such as sustainability, housing crises and economic equality can be addressed. The historic city buildings provide us with a large repository of natural and cultural heritage that illustrate a genuine and symbiotic relationship with the spirit of this unique place. This relationship, which is the true expression of knowledge and wisdom, is a valuable lesson for mainstream architects and urban planners to design new human settlements in the country. The meaningful environment of the Old City provides a wealth of knowledge for the professionals and academic institutions in the country and elsewhere to do their research and scholarly explorations. It also acts as a source of great inspiration for other multidisciplinary scholars, such as social scientists, ethnographers and urban economists, to seek a multitude of their research and scholarship needs.

\section{A CASE STUDY: MURAD KHANI NEIGHBORHOOD'S URBAN REGENERATION PROJECT}

Kabul's Old City is mainly situated in the south of Kabul River and comprises many historic quarters. These quarters are named either after a trade establishment or after the names of a tribe and tribal leaders. All these residential neighbourhoods are intertwined with commercial bazaars and public and religious buildings, which are tightly woven with the physical fabric of courtyard houses and accessed by narrow alleyways for circulation.

The two prominent traditional neighbourhoods located to the north-eastern section of the Old City include the Murad Khani district (named after Murad khan, a Qizilbash tribal, court official) [15] and Andarabi district [named after the people of Andarab coming to Kabul with transfer of the Khirqa (the robe of the prophet Mohammad)]. Both neighbourhoods were established during late 18th century when Timurshah Durani, the Afghan king, made Kabul the capital city of his rule. The areas have been heavily impacted by the war and have been in decline since then also as a result of neglect and unsustainable development.

The original historic conservation programme in the city was initiated by the AKTC in 2001 and a good number of historic structures were preserved, restored and rehabilitated in 
the neighbourhood of Asheqan wa Arefan and elsewhere in the Old City [16]. In the year 2006 the Murad Khani neighbourhood was selected for rehabilitation by the Turquoise Mountain Foundation (TMF), which followed the AKTC historic conservation programme guidelines [17]. The TMF was established in 2006 at the behest of HRH the Prince of Wales and then received the keen support of the president of Afghanistan.

The TMF conservation programme not only engaged vividly with the restoration of the physical historic buildings in the Murad-Khani historic district but also used this development as a vehicle to bring economic and cultural vitality to the whole neighbourhood. Within the sector of conservation the project aimed to restore and provide educational opportunities for the restoration of a variety of Afghan traditional art and craft production in this neighbourhood. Craft training schools and livelihoods of many craftsmen and skilled labourers within the neighbourhood were improved; under a socio-economic initiative supported by the Old City community, home-based training programmes and literacy improvement courses are also initiated for women (Figs. 4-7).

Being located close to the government entities, parts of the Murad Khani neighbourhood were already transformed into commercial buildings as of 1960s and streets widened later on. Murad Khani is well known for its Shia shrine, Abdul Fazel and the handmade industry of turning used tyres and tubes into workers shoes, beckets and rubber strips. Jewellers also have shops producing and trading with silver or silver-like jewellery normally worn by women of nomads and the communities at central highlands of Afghanistan.

Some fifty houses have been repaired and preserved, in a varied scale of investment, and a number of them are occupied by the TMF for their own offices. An institute training for young Afghans in carpentry, calligraphy, jewellery and glazed tiles has been established and their handiwork products are exported to clients in the Gulf and elsewhere. Today the rehabilitated area known as the historic Murad Khani covers an estimated area of $50,232 \mathrm{~m}^{2}$ or about 26 jeribs of land and is situated within the proximity of many urban facilities and employment centres. Its prominent landmark, the shrine of Abdul Fazel, is located at about $430 \mathrm{~m}$ from Puli-Khishti bridge over the Kabul River, which connects the north and south central commercial districts. The modern Kabul Bank building, the Serena Hotel, the Puli Khishti grand mosque and the old Seri-Shazda currency market each located within $400 \mathrm{~m}$ of each other.

The site is served by the city's transportation hub of passenger wagons and is close to many destinations in the city. The remaining section of the historic properties in Murad-Khani extends only as backyard structures, on Jade Nader Pashtoon side of the street with a length of $153 \mathrm{~m}$. Elsewhere one can also find areas that are totally transformed into multi-storied commercial structures.

Reconstruction work has focused on traditional Afghan techniques and the traditional building material of stone, raw bricks, wood and saturated mud. Engineer Hedayatullah Ahmadzai is responsible for the overall project management of the urban regeneration work in Murad Khani, where a number of international architects and engineers helped in the process of restoring the historic buildings and improving the streets in the neighbourhood during the five years of the project, which ended in 2010. This restoration was acknowledged by UNESCO's Asia-Pacific Award of Distinction in 2013 [18]. A few of the houses are now accommodating a library, workspaces for students and the office of TMF cultural programmes, including an institute to train young Afghans in the traditional styles of making woodwork, calligraphy, pottery and jewellery.

Other activities to enhance the physical status of the neighbourhood were to install about $200 \mathrm{~m}$ of drainage and provide drinking water and pave streets with stone. The TMF indicated 


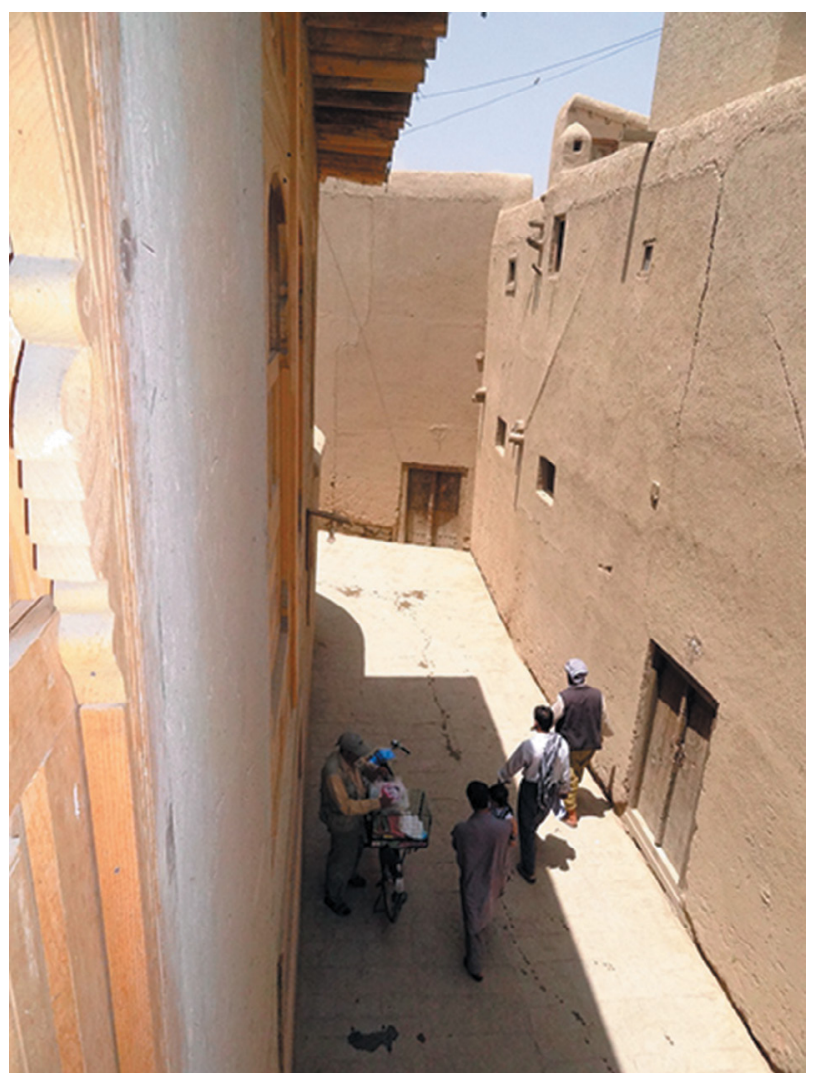

Figure 4: A rehabilitated alleyway in the residential complex.

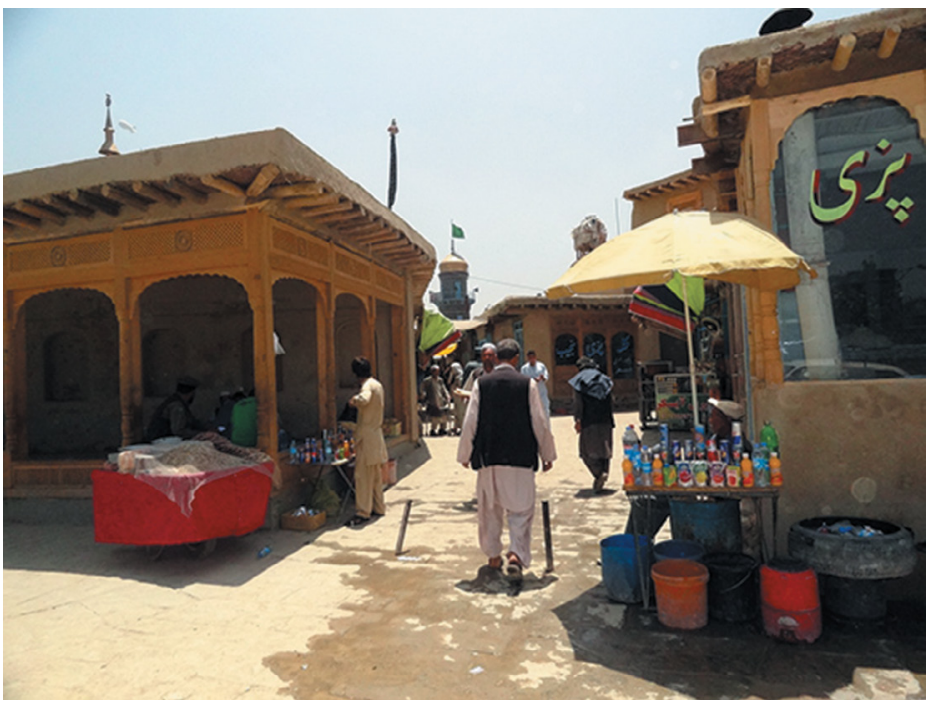

Figure 5: A rehabilitated commercial bazaar. 


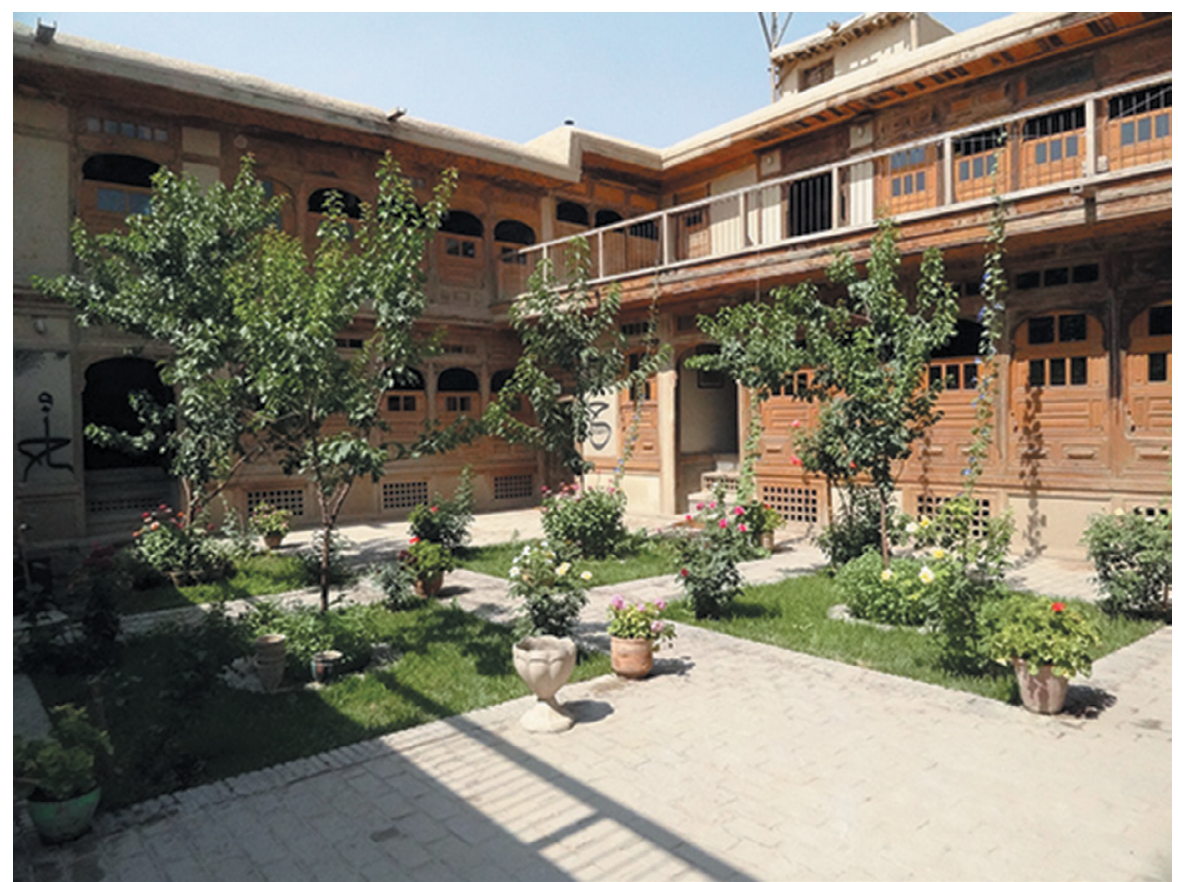

Figure 6: A courtyard house in Murad Khani district. Restoration by the TMF.

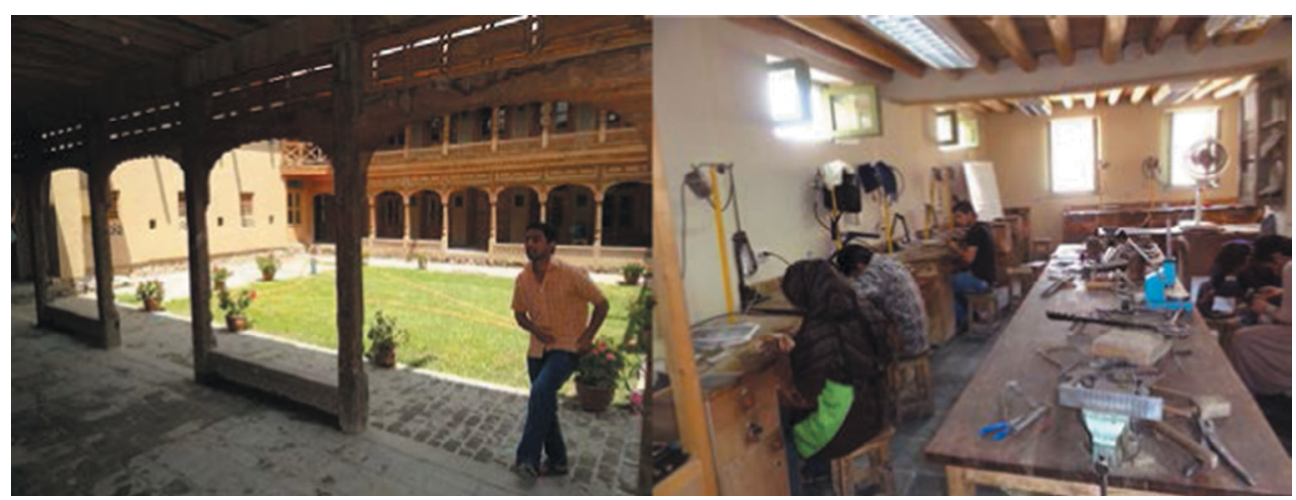

Figure 7: (a) Training school with courtyard for Afghan art and craft. (b) An interior of a classroom. Restoration by the TMF.

that the total cost of complete preservation and maintenance for Murad Khani is estimated at $\$ 4.9$ million, which has been supported by different donors internationally, especially the US, Canada, Britain and India [19].

The pressure from commercial development and the infringement by government offices like the Ministry of Finance, which is located in the vicinity of the project, is extremely high and would challenge the sustainable conservation of the site, unless protected by cultural heritage law; the Afghan Heritage Saving Law of 2004 could be instrumental in prohibiting the encroachment of new buildings and saving historic areas. Despite these threats Murad Khani 
retains some of its original historic fabric with a network of small streets, a bazaar, a religious structure and courtyard houses, all of which represent a successful regenerative conservation project in Kabul's historic neighbourhoods.

\section{CONCLUSION}

Historic Kabul's tumultuous past, shattered by the misfortunes of war and present meagre reconstruction opportunities, inspire us with a deeper spirit of responsibility in heritage survival and conservation.

Revitalizing the historic city will improve not only the economic status of the area but also enhance the social conditions of its inhabitants, who now occupy the historic district. Among the important resources in the city is the motivation and skills of the population itself, which has to be mobilized on a massive scale. Studies show that many of the active workforce living in the Old City find employment in construction-related jobs or in the small-scale production industry. Harnessing the abilities of those who have some skills especially in the traditional building techniques of masonry, carpentry and building repair, we can find a range of talents that could prove to be important benefits to the conservation and reconstruction process.

Traditional building technologies and materials will continue to present affordable shelter building to the majority of people in the city. This is so because people take advantage of selfhelp processes and participatory approaches to build shelters most economical and within their means of affordability. Building with local materials and incrementally improving their houses is within their means to accommodating their growing family needs. Setting up a selfhelp building advisory service by the government authorities to encourage higher standards of construction is an effective approach in sustaining the reconstruction process. Government and aid organizations can assist in small financing schemes over long periods of time to the residences, secured by the dwelling and land values itself.

Housing cooperatives and lending organizations that are secured by the government guarantees can be more effective in providing financial help for restoration, repair and lending to individuals to improve their dwellings [20]. The government should provide help with the provision of infrastructure and services (such as sewer, water, electricity, education and health facilities on these sites), which also may require incremental development in stages as funds become available.

Courtyard houses, which are widely used in the Old City, are an excellent shelter prototype employing favourable climatic strategies for comfortable living of the families. The layout and architecture of the courtyard houses are strongly affected by the Islamic culture and lifestyle seeking to establish privacy and identity for the families. The houses are inward looking and open to a central garden. They are of varied sizes and ranges from one to three stories in height. Traditionally the courtyards included several living quarters, which accommodated a larger number of extended families and provided much higher densities. The repair of many of these houses, which have been damaged or abandoned by the population during wartime, can provide affordable shelter choice, which is already conducive to the lifestyles of the inhabitants. In addition the restoration and revitalization process will build confidence among the community members and leaders in the Old City to commit to safeguarding their valuable surviving historic heritage.

There is great need for conservation and survival of rich historical and cultural heritage in Kabul as it contributes to the cultural asset of the entire city. The historic city built and restored to its original splendour will certainly provide great opportunity and stimulus for the economy and foster a familial sense of place where people take ownership of their built environment and live with dignity. 


\section{REFERENCES}

[1] Dalrymple, W., Mes Aynak: Afghanistan's Buddhist buried treasure faces destruction. The Guardian, May 2013 (accessed 1 September 2015).

[2] http://www.nationalmuseum.af/component/content/article/88-ArchaeologicalSites/3534-Tape-Narinj (accessed 12 September 2015).

[3] Paiman, Zafar, 7th century Buddha - Kabul, 2015. http://www.afghanculturemuseum. org/portrait-zafar-paiman/ (accessed 2 September 2015).

[4] Arifi, Abdul Ghafoor, Urban policies, planning and implementation in Kabul, Afghanistan, UMP Dissertation Service, A Bell \& Howell Company: Ann Arbor, MI, pp. 8-10, 2001.

[5] Dupree, L., Afghanistan, Princeton University Press: USA, 1973, (reprinted 2014), p. 340.

[6] Dupree, N.H., Victoriana comes to the Haremserai in Afghanistan. Bauen und Wohnen am Hindukush, Biblioteca, Liestal: Afghanistan, 1988.

[7] Kabul iii. History from the 16th century to the accession of Zāher Shah, May Schinasi, Vol. XV, Fasc. 3, pp. 303-306, 19 April 2012.

[8] Schadel, Marcus, Development of Kabul: Reconstruction and Planning Issues, eds. Babur Mumtaz \& Kaj Noschis, 10th Architecture \& Behaviour Colloquium, Monte Verita, Ascona, Ticino, Switzerland, p. 16, 4-7April 2004.

[9] Chua, Andrew, The promise and failure of King Amanullah's modernization program in Afghanistan. The ANU Undergraduate Research Journal Volume Five 2013, ANU Press: Canberra, Australia, pp. 35-36, 2014.

[10] Gopalakrishnan, R., The Geography and Politics of Afghanistan, Concept Publishing Company: Delhi, 1982.

[11] Najimi A.W. \& Leslie J., Urban recovery: The case of historic Kabul. Heritage and Sustainability in the Islamic Built Environment, ed. B.A. Kazimee, Washington State University: USA, pp. 23-37, 2012.

[12] Tang, Alisa, Kabul's old city gets a new look. New York Times (1 February 2008).

[13] http://www.nytimes.com/2008/01/21/world/asia/21ihtkabul.1.9371270.html?_r=0 (accessed 2 September 2015).

[14] Najimi, A.W., Building Kabul: Mimar, architects and engineers, Federal Institute of Technology Lausanne (ENAC, EPFL)/AKTC, 2004, Parametro: Rome, p. 272, 2007.

[15] AKTC. Urban conservation and area development in Afghanistan, 2007. Historic Cities Program, Geneva, available at www.akdn.org (accessed 12 September 2015).

[16] Rondeaux, Candace, Restoring past glory in Old Kabul Washington Post Foreign Service, Sunday, July 6, 2008, available at http://www.washingtonpost.com/wp-dyn/content/article/2008/07/05/AR2008070501839.html (accessed 12 September 2015).

[17] The Turquoise Mountain Foundation, available at http://turquoisemountain.org (accessed 12 September 2015).

[18] UNESCO Awards of Distinction: The Great Serai, Kabul, Afghanistan, 2013, available at http://www.unescobkk.org/culture/wh/asia-pacific-heritage-awards/previous-heritageawards-2000-2013/2013ha1/ (accessed 12 September 2015).

[19] Rasool, Dad, Rebuilding Afghanistan's creative industries. The British Council, available at http://www.britishcouncil.org/blog/rebuilding-afghanistans-creative-industries, 2013 (accessed 12 September 2015).

[20] Kazimee, B.A., Sustainable reconstruction and planning strategies for Afghan cities: Conservation in cultural and environmental heritage. WIT Transactions on Ecology and the Environment, Vol. 93, WIT Press, 2006, ISSN 1743-3541. 